\title{
Zagospodarowanie Podzamcza w Lublinie - głos w dyskusji o budynku Nadstawna 2-4
}

\author{
Lukasz Borowski ${ }^{1}$, Olga Skoczylas ${ }^{2}$, Krzysztof Nepelski $^{3}$ \\ ${ }^{1}$ Katedra Geotechniki, Wydziat Budownictwa i Architektury, Politechnika Lubelska, \\ e-mail: l.borowski@pollub.pl \\ ${ }^{2}$ Samodzielna Pracownia Architektoniczna, Wydziat Budownictwa i Architektury, Politechnika \\ Lubelska,e-mail: o.skoczylas@pollub.pl \\ ${ }^{3}$ Katedra Geotechniki, Wydziat Budownictwa i Architektury, Politechnika Lubelska, \\ e-mail:k.nepelski@pollub.pl
}

Streszczenie: W publikacji przestawiono dyskusję na temat przyszłości budynku Nadstawna 2-4 w Lublinie. Powodem są zmiany jego funkcji zapisane w nowym Miejscowym Planie Zagospodarowania Przestrzennego (05.2015 r.) dla obszaru Podzamcza: z usługowej (handlowej, biurowej) na mieszkalną z częścią usługową, a także jego zły stan techniczny. Nowy właściciel budynku (od 02.2015 r.) jest zatem postawiony przed wyborem: remont budynku z możliwym zachowaniem jego aktualnej funkcji, bądź budowa nowego zgodnie z aktualnym planem miejscowym. Autorzy uważają, że wynik tej decyzji będzie istotny dla zagospodarowania przestrzeni tej części miasta.

Badania autorów obejmowały analizy: stanu technicznego budynku, inwestycyjnej w nowy obiekt, a także optymalnego zagospodarowania, modernizacji i rozbudowy obiektu oraz jego wpływu na otaczającą przestrzeń. Nacisk położono też na badanie przyczyn i wyników osiadania budynku.

Słowa kluczowe: przyszłość Podzamcza, modernizm w Lublinie, osiadanie budynku, sondowanie CPT.

\section{Wstęp}

Budynek PZU, przy ul. Nadstawnej 2-4, jest charakterystycznym obiektem Śródmieścia Lublina. Już od początku lat 70tych XX wieku budynek był przedmiotem badań i analiz ze względu na jego nierównomierne osiadanie. Ostatnie tego typu prace zostały wykonane w 1994 r. przez pracowników Politechniki Lubelskiej. Po 21 latach przerwy autorzy niniejszej publikacji powrócili do zbadania tego obiektu. Przez ten czas budynek był wyłączony z eksploatacji (2006 r.), a następnie sprzedany (2015 r.). W 2015 r. dla obszaru Śródmieścia został uchwalony miejscowy plan zagospodarowania terenu. Powyższe zmiany są okazją do dyskusji na temat przyszłości obiektu. Przede wszystkim próbujemy odpowiedzieć na pytanie, czy Inwestor powinien dokonać adaptacji obiektu czy wybudować nowy?

\section{Nadstawna 2-4: stan obecny oraz przyszłość wg. planu miejscowego}

Budynek biurowy przy ul. Nadstawnej 2-4 powstał w $1953^{1}$ r. i był wykorzystywany nieprzerwanie do 2006 przez PZU S.A. Od tamtej pory pozostaje nieużytkowany. W 2015 roku w wyniku przetargu nastąpiła jego sprzedaż. Cena wyjściowa została podbita prawie

${ }^{1} \mathrm{~W}$ miejskim rejestrze transakcji nieruchomości jest zapisana data $1946 \mathrm{r}$. 
dwukrotnie (z 1,04 mln dla 1,96 mln zł), co wskazuje na zainteresowanie inwestorów centrum Lublina [1][2].

Przyjęte przepisy w planie miejscowym zezwalają na zachowanie dotychczasowej funkcji budynku w przypadku jego przebudowy. Natomiast w przypadku budowy nowego obiektu plan przewiduje funkcję mieszkalną i usługową. Cześć usługowa nie może przekraczać 30\% powierzchni użytkowej. Dla maksymalnie 5 kondygnacyjnej zabudowy (obecnie 3 dla większości budynku) oznacza to wykorzystanie parteru, z ewentualną dodatkową powierzchnią na piętrze np. w narożniku ulic Nadstawnej i Nowego Placu Targowego, pod funkcję komercyjną. W planie przewidziano zachowanie obecnej linii zabudowy wzdłuż ul. Nadstawnej/Nowy Plac Targowy oraz wewnętrznego dziedzińca (Rys 1). Dopuszczalne jest zatem powiększenie powierzchni nowego obiektu przede wszystkim w miejscu istniejącej drogi dojazdowej do dziedzińca (Nadstawna 4). Zabudowana część wewnętrznej dziedzińca jest ograniczona ze względu na wymiary działki.

Zgodnie z planem miejscowym budynek ma stanowić część kwartału zabudowy ograniczonego drogami publicznymi. Wyjątkiem jest północny-wschodni sąsiad kwartału, oznaczony jako 4KP (Rys. 1), który przeznaczony jest pod nowe targowisko miejskie.

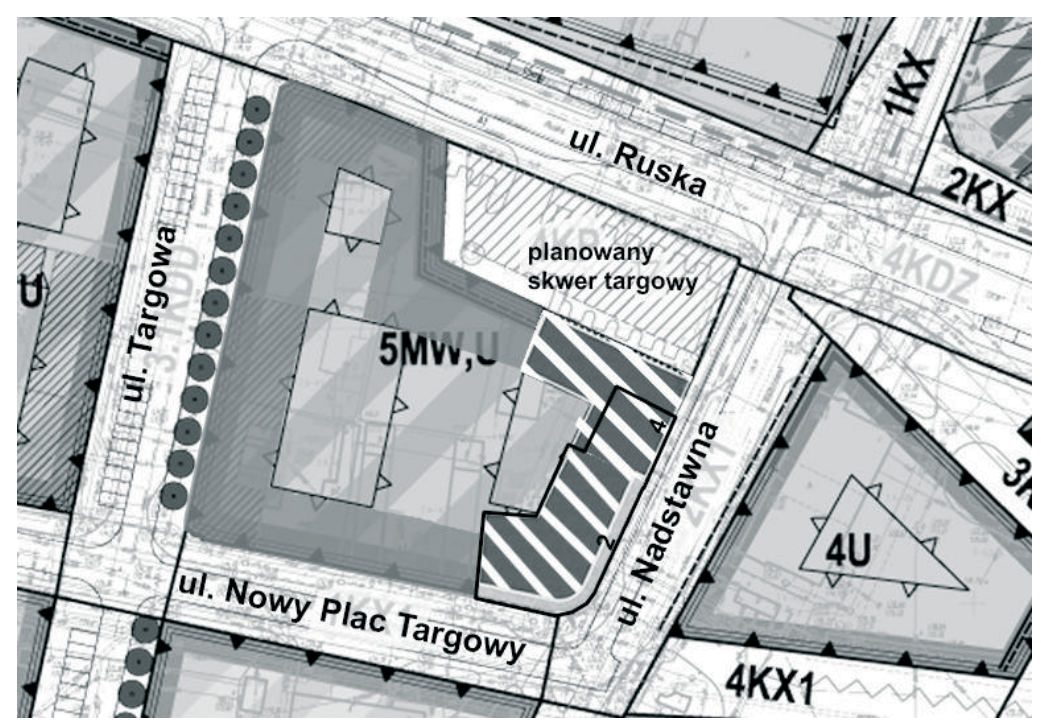

Rys. 1. Przykład zabudowy kwartału. Czarną obwódką zaznaczono istniejącą część budynku Nadstawna 24, białym kreskowaniem potencjalną przebudowę i rozbudowę

\section{Perspektywy dla nowego obiektu}

Budowa nowego budynku, zgodna $\mathrm{z}$ obwiązującym planem miejscowym, była przedmiotem uproszczonych analiz wykonanych dla różnych scenariuszy. Finalnie możemy stwierdzić, że koszt budowy powierzchni użytkowej lokali zawiera się w granicach 4650 $5850 \mathrm{zl} / \mathrm{m}^{2}$ (patrz: Rozdział 3.1) w zależności od przyjętych rozwiązań technologicznych i estetycznych przez Inwestora (obiekt typowy lub podwyższony standard). Do tej wartości należy dodać koszt rozbiórki istniejącego budynku. Podane wartości zostały obliczone dla budynku podwyższonego o jedną kondygnację mieszkalną, rozbudowanego w północnej części działki. Odtworzenie istniejącej powierzchni nie jest ekonomicznie zasadne. Przy tak wysokim koszcie działki oraz budowy cena $\mathrm{m}^{2}$ musi wykraczać poza segment popularny 
(4500-5000 zł/m²) sprzedaży nowych mieszkań w Lublinie. Jakkolwiek obiekt jest zlokalizowany w ścisłym centrum miasta, to jednak uważamy, że istnieje szereg negatywnych czynników, które sprawiają, że sprzedaż lokali jako segment premium jest obaczona wysokim ryzykiem. Do tych czynników należy zaliczyć:

- niską reputację okolicy (rejon ul. Lubartowskiej),

- podwyższony hałas, wynikający z ruchu kołowego i pieszego,

- brak pozytywnego wpływu innych inwestycji tym rejonie (najbliższa inwestycja znajduję się ok. $0.8 \mathrm{~km}$ )

- uciążliwe sąsiedztwo dworca PKS oraz dwóch mało estetycznych targów miejskich (ul. Ruska, ul. Nowy Plac Targowy),

- występowanie mało prestiżowej działalności gospodarczej (sprzedaż nielegalnych wyrobów alkoholowych, a przede wszystkim tytoniowych).

Podane wady okolicy mogą zostać zniwelowane na skutek inwestycji w myśl przepisów aktualnego planu miejscowego (np. budowa hali targowej przy ul. Ruskiej, zmniejszenie dworca PKS, nowe inwestycje mieszkalne i usługowe). Część z tych inwestycji jest planowanych w najbliższej przyszłości [3]. Uważamy jednak, że wymaga to dłuższej perspektywy czasowej, być może rozciągniętej do nawet 10 lat. Na dzień dzisiejszy potencjalnie zyskowną inwestycją jest sprzedaż mieszkań obiektu typowego w cenie pomiędzy segmentami rynku: popularnym a premium. Przy $20 \%$ marży dla inwestora cena $\mathrm{m}^{2}$ powinna wynieść pomiędzy 5150 a 5650 zł (z VAT). Podana rozpiętość jest tylko uproszczeniem. Cena została zróżnicowana wyłącznie ze względu na kondygnację. Dodatkowymi ważnymi czynnikami sprzedaży jest powierzchnia, orientacja i rozkład mieszkania, a także balkon/taras oraz widok z okien. Stąd też bardziej prawdopodobna jest większa rozpiętość cen: 5100-5900 za m². Oszacowane ceny są porównywalne do oferowanych w okolicy (ul. Obywatelska: 5100-5500 zł), co jest okolicznością sprzyjającą sprzedaży.

Zupełnie inaczej przedstawia się perspektywa dla części handlowo-usługowej stanowiącej parter budynku. Sąsiadujące obiekty: dworzec i targi generują duży ruch konsumentów. Jest to zatem bardzo dobra lokalizacja dla handlu i usług, w szczególności dla branży $\mathrm{FMCG}^{2}$ (np. supermarket, drogeria samoobsługowa itp.). Budowa nowego obiektu nie wpłynie na powiększenie przestrzeni handlowej parteru, a zmniejszy możliwość wykorzystania na ten cel wyższych pięter. Stąd alternatywą wobec budowy nowego obiektu jest remont generalny części Nadstawna 2 wraz z budową nowego (większego) obiektu Nadstawna 4. Jednym z elementów takiej wersji przebudowy jest potencjalna możliwość wprowadzenia części usługowej od strony planowanego targu miejskiego (Nadstawna 6), co wymaga jednak uzgodnienia dostępu do tego placu. Kwestia ta jest kluczowa dla inwestycji. W przypadku możliwości wprowadzenia obiektów handlowych lub biurowych na poziomie 1 kondygnacji dla tej części obiektu nastąpi znaczne powiększenie rentowności inwestycji.

\subsection{Analiza budowy nowego obiektu}

Opracowana przez autorów analiza zawierała różne scenariusze budowy. Wstępne wyniki wskazały, że odtworzenie istniejącej powierzchni budynku nie jest ekonomiczne zasadne. Stąd w publikacji prezentujemy wyłącznie obiekt składający się z 5 kondygnacji nadziemnych oraz 1 podziemnej opracowany w dwóch wariantach: typowym oraz o podwyższony standardzie. Założono, że w nowym obiekcie wyłącznie parter jest przeznaczony na cele handlowe. Pozostałe zaś piętra służą do celów mieszkalnych. W obu rozważanych wersjach przyjęto finansowanie ze środków własnych inwestora dla obsługi budowy (zakup

\footnotetext{
2 fast-moving consumer goods - produkty konsumenckie szybko zbywalne.
} 
działki, projekt, uzgodnienia, ogrodzenie i pilnowanie budowy, ubezpieczenia oraz sprzedaż lokali). Natomiast kredytowana jest sama budowa (oprocentowanie 6.8\% na 2 lata, $0.5 \%$ prowizji).

Koszty budowy zostały obliczone na podstawie analiz cen w budownictwie [4] oraz wywiadu z wykonawcami prac budowanych. Wyjątkiem jest koszt wzmocnienia fundamentów (palowania), który został określony wyłącznie na podstawie ofert firm. Koszt sprzedaży lokali został oszacowany pomiędzy 3-4\% procent wartości inwestycji (wyższy dla podwyższonego standardu) i obejmuje m.in. obsługę przez 1 pracownika, oraz prowizję za sprzedaż lokali. Łączny koszt został przedstawiony w Tabeli 1 . Zawarte dane można także przeliczyć na koszt budowy $\mathrm{m}^{2}$ powierzchni użytkowej lokali. W tym wypadku wynosi ona $4650 \mathrm{zł}$ dla obiektu typowego oraz $5850 \mathrm{zł}$ dla podwyższonego standardu. Wartości te nie obejmują rozbiórki istniejącego obiektu.

$\mathrm{Na}$ podstawie oszacowanych kosztów określiliśmy minimalne wartości cen powierzchni użytkowej lokali, tak by koszty i wpływy ze sprzedaży równoważyły się. Do podanych wartości (Tabela 2) należy doliczyć marżę inwestora oraz podatek VAT (8\% dla mieszkań oraz 23\% dla usługowych). Przyjęto za najbardziej atrakcyjne dla konsumentów 2 i 3 piętro. Najmniej atrakcyjne zaś piętro pierwsze, na co składa się wyższe oddziaływaniem otoczenia oraz przeciętny widok z okien. Oddzielą kwestią pozostaje parter. Inwestorów części handlowo-usługowej znacznie mniej interesuje standard całego budynku. Stąd też przytoczone wartości są przybliżone. Możliwe jest, że cena $\mathrm{m}^{2}$ sprzedaży tej części budynku będzie porównywalna dla obu wersji.

Tabela 1. Oszacowany koszt budowy nowego obiektu 5 kondygnacyjnego (w zł bez VAT)

\begin{tabular}{crr}
\hline Koszty: & \multicolumn{2}{c}{ Standard budynku: } \\
\cline { 2 - 3 } & 1960000 & \multicolumn{1}{c}{ podwyższony } \\
\hline Działka & typowy & 1960000 \\
Obsługa budowy & 585559 & 585559 \\
Budowa & 6778960 & 9200018 \\
Palowanie & 300000 & 300000 \\
Kredyt & 536821 & 720418 \\
Sprzedaż & 300000 & 420000 \\
\hline Razem: & $\mathbf{1 0 4 6 1 3 4 0}$ & $\mathbf{1 3 ~ 1 8 5 9 9 5}$ \\
\hline
\end{tabular}

Tabela 2. Minimalna cena $\mathrm{m} 2$ powierzchni użytkowej lokali opracowana tak, by zwróciła koszty budowy nowego obiektu (bez marży inwestora i VAT)

\begin{tabular}{ccc}
\hline \multirow{2}{*}{ Piętro } & \multicolumn{2}{c}{ Standard budynku: } \\
\cline { 2 - 4 } & typowy & podwyższony \\
\hline garaż & 1379 & 2085 \\
parter & 5716 & 7040 \\
I & 3983 & 5051 \\
II & 4366 & 5452 \\
III & 4366 & 5452 \\
IV & 4136 & 5212 \\
\hline
\end{tabular}

\section{Modernizacja}

Alternatywą do budowy nowego obiektu jest remont kapitalny istniejącego, dostosowujący do współczesnego standardu handlowego i biurowego. Jednakże wyłączenie obiektu z użytkowania było spowodowane jego złym stanem technicznym, objawiającym się 
licznymi pęknięciami ścian. Nasze badania dotyczyły także rozwiązania kwestii dalszego pogłębiania się tego stanu. Przeprowadzone analizy wykazały konieczność wzmocnienia fundamentów obiektu (patrz: Rozdział 4.1).

Jedną z kwestii modernizacji istniejących obiektów jest jej zakres - ingerencja w istniejący obiekt. W szczególności dotyczy to stopnia odejścia od jego pierwotnego wyglądu, często trwale wpisanego w otaczającą przestrzeń, czy istniejącego w lokalnej świadomości społecznej. Budowa nowego obiektu może doprowadzić do zniszczenia „ducha miejsca” (genius loci), a przez to spowodować szkodę w przestrzeni publicznej. Stąd też postulowane są ingerencje architektoniczne, w których „nowa tożsamość” poszanuje „kod identyfikacyjny" miejsca [5]. Naszym zdaniem możliwa jest adaptacja obiektu, z częściową rozbudową, która spełni powyższy postulat (patrz: Rozdział 4.2.).

\subsection{Badanie przyczyn i prędkości osiadania obiektu}

Głównym problemem obiektu są jego zarysowania i pęknięcia pojawiające się na wszystkich ścianach budynku (Rys 2). Dodatkowo można zauważyć osiadanie posadzki piwnic. Wynika to ze specyfiki podłoża gruntowego na którym posadowiono budynek. Bezpośrednio pod piwnicami zalegają grunty nienośne w postaci plastycznego pyłu, namułu oraz torfu. Podłoże nośne stanowią piaski średnie i drobne, których strop występuje na głębokości około 8 metrów poniżej poziomu terenu [7,8]. Posadowienie budynku na tym podłożu zostało wykonane poprzez zastosowanie drewnianych pali fundamentowych, jednakże w latach 50-tych technologie głębokiego posadowienia nie były tak zaawansowane jak dzisiaj. Przede wszystkim nie było możliwości kontrolowania bieżącego oporu gruntu podczas prac fundamentowych, stąd nie ma pewności, czy wszystkie pale opierają się w gruncie o wystarczającej nośności. Nierównomierne osiadanie budynku (przyczyna jego uszkodzeń) wskazuje na brak oparcia dla części pali.
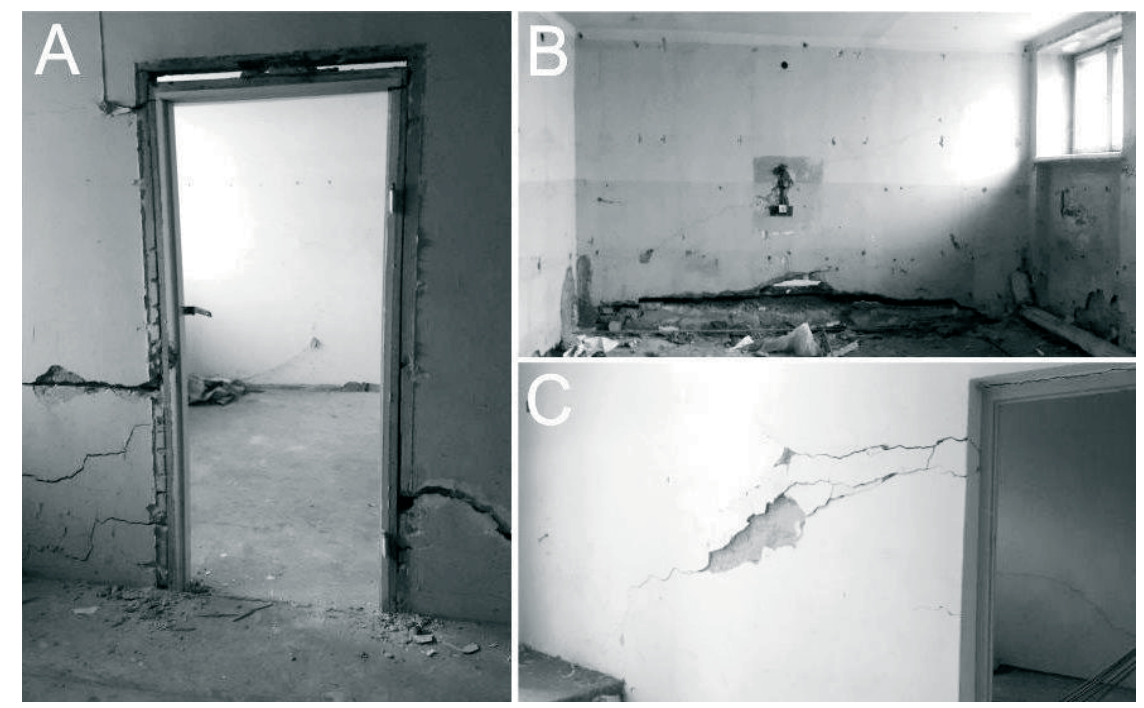

Rys. 2. Wyniki osiadania budynku: spękania ścian i odspojenie futryny drzwiowej (A), pęknięcie ściany i odspojenie od posadzki (B), pękanie ścian na klatce schodowej (C)

W celu zweryfikowania przyczyn oraz ustalenia zakończenia procesu osiadania przeprowadziliśmy badania podłoża gruntowego oraz pomiary osiadania. Badanie podłoża polegało na wykonaniu sześciu sondowań statycznych sondą CPT z mechanicznym stoż- 
kiem Begemanna, a następnie porównaniu ich z archiwalnymi [7] profilami wiertniczymi (Rys. 3). Wyniki wskazują na występowanie warstw nośnych na głębokościach od około $8 \div 11,5$ m poniżej poziomu terenu. W przypadku dwóch sondowań (CPT-5 i CPT-6) [8] pojawia się warstwa przejściowa. Jest to prawdopodobnie jedna z przyczyn osiadania budynku - cześć pali mogła zostać posadowiona na tej warstwie. Badanie tempa osiadania polegało na wykonaniu pomiarów niwelacyjnych sieci reperów, których wyniki zostały odniesione do danych archiwalnych z lat 1980-1993 r. Proces osiadania budynku nie jest zakończony. Dla dwóch głównych miejsc osiadania (Rys. 4), prędkość zmiany utrzymuje się na stałym poziomie ok. $0.8 \mathrm{~mm} /$ rok. Jedynym miejscem spowolnienia tego procesu jest północno-wschodnia część budynku Nadstawna 4 (reper 19). Miejsce to w latach 80-94 także podlegało silnemu ruchowi pionowemu, obecnie zaś stabilność jest porównywalna do pozostałej części obiektu.

Wykonane badania, jak również analiza konstrukcji obiektu oraz wyniki wizji lokalnej, umożliwiają wnioskowanie o przyczynach nierównomiernego osiadania budynku. Wykonane palowanie w części obiektu jest zbyt płytkie. Układ pali pod konstrukcją budynku jest nieznany, ale jest bardzo prawdopodobne, że są rozmieszczone w sposób powodujący ich nierównomierne obciążenie i przeciążenie niektórych pali. Dodatkowym czynnikiem wpływającym na przechylanie się budynku w stronę ulicy Nowy Plac Targowy jest ciągły ruch kołowy, na zniszczonej nawierzchni, co powoduje dodatkowe obciążenia dynamiczne. Czynnik ten powoduje ogólne osiadanie całego obiektu z prędkością ok. $0.1 \mathrm{~mm} / \mathrm{rok}$.
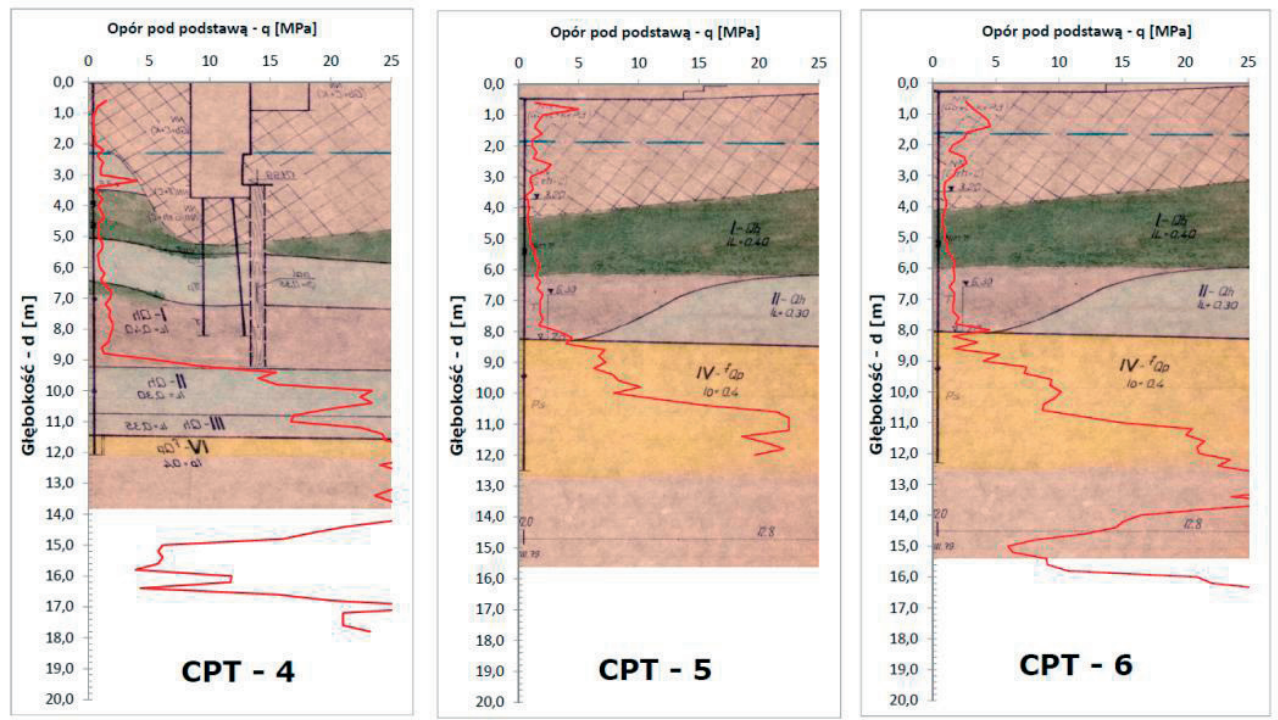

Rys. 3. Archiwalne profile gruntu z naniesionymi wynikami sondowania CPT

Wzmocnienie fundamentów umożliwi dalsze użytkowanie budynku. Przede wszystkim musi dotyczyć ściany elewacyjnej, a w przypadku obniżenia stropu parteru, także w miejscach jego podparcia. Wymaga to dodatkowego palowania. Prace związane z głębokim fundamentowaniem w zabudowie istniejącej są kosztowne, ze względu na konieczność stosowania odpowiednich maszyn oraz wydłużonego czasu realizacji. Przy omawianym budynku oszacowany koszt wzmocnienia fundamentów będzie wynosił ok. $0.5 \mathrm{mln}$ zł. Jest to wyższa wartość od oszacowanej w przypadku palowania dla zupełnie nowego (rozbudowanego) obiektu (ok. $0.3 \mathrm{mln} z \nmid)$. 


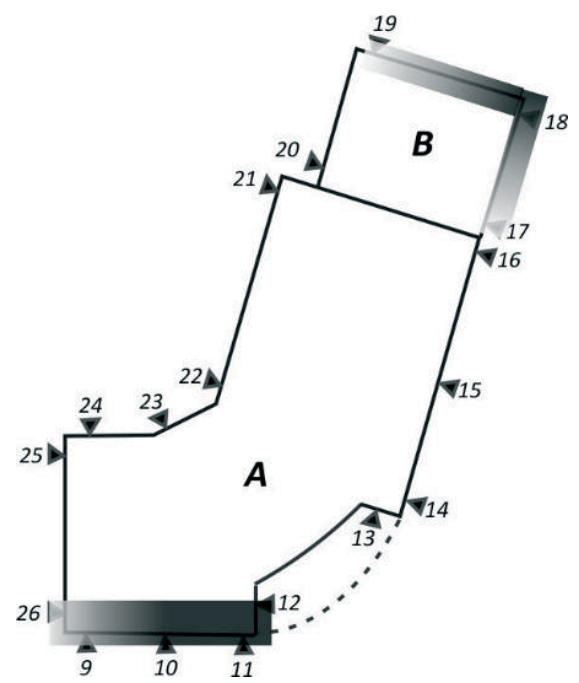

Rys. 4. Główne miejsca osiadania obiektu (zobrazowane szarymi prostokątami o gradiencie barwy odpowiadającej wartości osiadania) zaznaczone na schemacie obiektu z naniesioną siecią reperów

\subsection{Propozycja modernizacji}

Budynek został zaprojektowany przez arch. Jana Ogórkiewicza. Projektant zadbał o wkomponowanie obiektu w tkankę miejską, wyznaczając w ten sposób śródmiejski charakter kierunku odbudowy Podzamcza. Charakterystycznym elementem jest zaokrąglony narożnik, który mocno wpisał się w świadomość mieszkańców Lublina - od niego wzięła się potoczna nazwa budynku „okrąglak” (Rys. 5). Róg jest zaakcentowany też przez umiejscowienie wejścia do obiektu w tym miejscu oraz zastosowanie szklanych pustaków doświetlających klatkę schodową i hol. Jest elementem, w którym widać inspirowanie się architekturą dobrego modernizmu $\mathrm{z}$ lat 30 . Z tego względu obiekt PZU zasługuje na ochronę i zachowanie w tkance miejskiej. Podobne zdanie mają uchwalający plan miejscowy oraz szerokie grono osób zgłaszających uwagi do niego [6].

Powaga obiektu została podkreślona schodami, zarówno na zewnątrz budynku, jak i w jego wnętrzu (Rys. 6). Skłania to wchodzącego do podniesienia głowy i spojrzenia na majestat instytucji, która ówcześnie miała w budynku swoją siedzibę. Dzisiaj nie potrzeba podkreślać powagi i oddalać potencjalnego klienta od funkcji zlokalizowanej w budynku. Raczej dąży się do skrócenia tego dystansu. Lokalizacja schodów przy wejściu jest ważna również ze względu na dostępność obiektu dla niepełnosprawnych, matek z dziećmi czy osób starszych. Oczywiście można pokonać każdą barierę architektoniczną przez podnośniki czy platformy, jednak najlepszym rozwiązaniem jest jej usunięcie. Zwłaszcza, że jest także podświadomą przeszkodą dla osób o pełnej sprawności ruchowej. Dla współczesnych obiektów handlowych istnienie barier wejścia do środka jest wadą. Dodatkowo wysoki poziom parteru ponad ulicą uniemożliwia ekspozycję przedmiotów handlu w witrynach okiennych. Dostosowanie do planowanych nowych funkcji może się odbyć poprzez obniżenie podłogi parteru, a przez to likwidację wewnętrznych schodów wejściowych. W ten sposób zostanie obniżony sufit w piwnicach, przekształcając je z pełnoprawnych kondygnacji (obecne rozwiązanie) do typowych piwnic (o wysokości 2-2,20 m). Obniżenie parteru do poziomu ulicy (z likwidacją schodów zewnętrznych) oznacza rezygnację z piwnic, jest zatem dyskusyjne. 


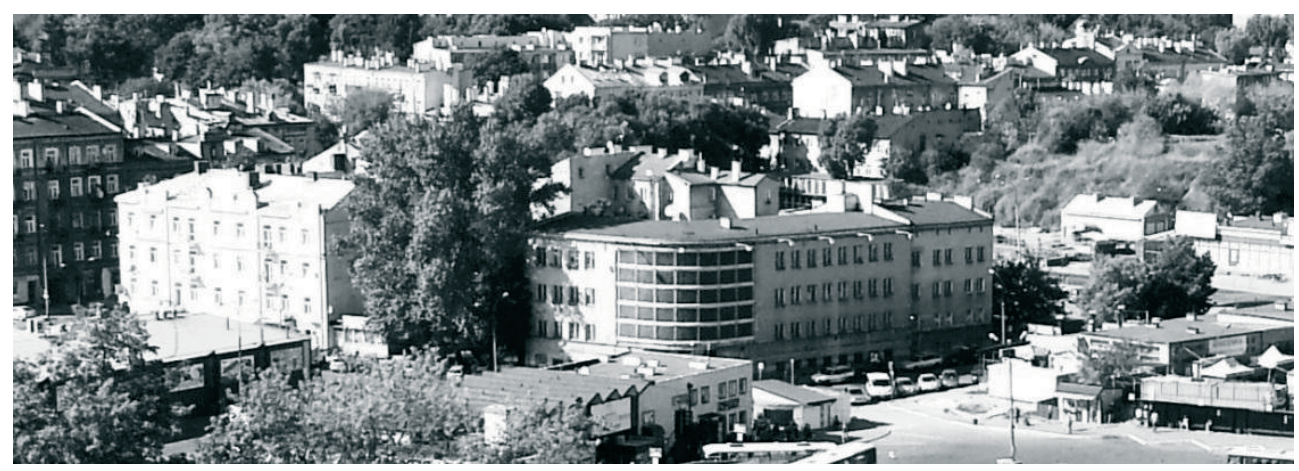

Rys. 5. Kwartał zabudowy widziany z donżonu na Zamku Lubelskim. Mocno wyeksponowany budynek przy ul. Nadstawna 2-4. (fot. własna, 2015r.)
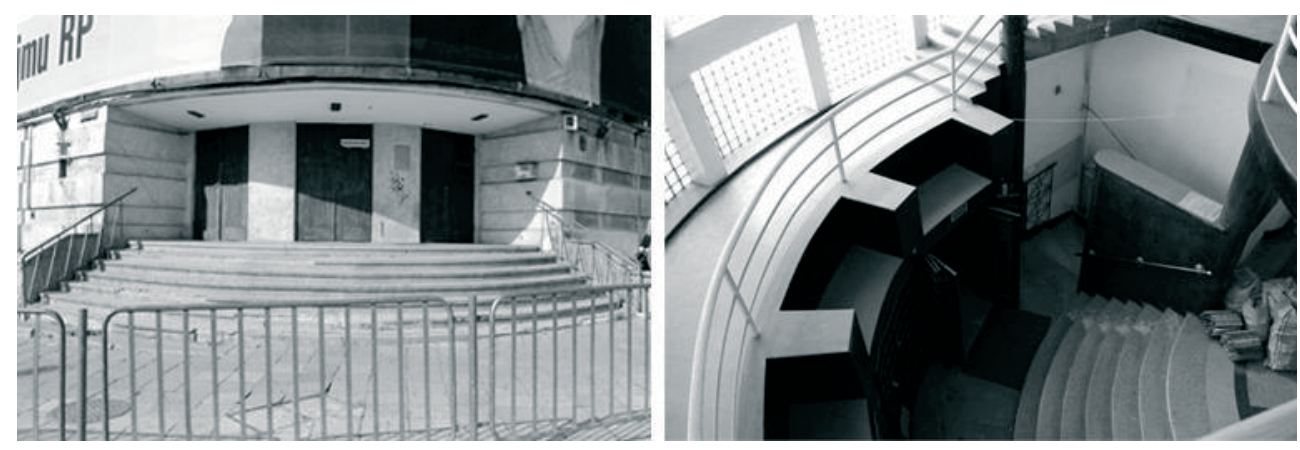

Rys. 6. Po lewej: Główne wejście do budynku. Po prawej: Wewnętrzne schody przy wejściu (fot. własne, 2015 r)

Potencjalne podwyższenie budynku o jedną kondygnację może napotkać na szereg utrudnień. Jednym z nich jest konieczność dalszego wzmacniana fundamentów, co może skutkować nieopłacalnością tego elementu inwestycji. Jednakże w przypadku możliwości podwyższania budynku o jedną kondygnację, zarówno w przypadku modernizacji jak i budowy nowego, jego dobre proporcje wymagają, aby ta kondygnacja została cofnięta względem istniejących. W ten sposób budynek, który sprawia wrażenie masywnego, nie zostanie obarczony dodatkowym ,ciężarem”, a przez to nie będzie dominował nad sąsiadującą kamienicą. Powstałą w ten sposób wolną powierzchnię można wykorzystać na tarasy dla mieszkańców.

Nowsza część obiektu (Nadstawna 4) nie jest wartościowa pod względem architektonicznym, dlatego nie ma powodów, by ją zachować. Dodatkowo jest to rejon działki, który umożliwia rozbudowę całego obiektu. Zatem adaptacja całego obiektu jest możliwa poprzez remont części starszej - narożnej (Nadstawna 2) z zupełnie nową budową w części nowszej. Istotną komplikacją jest jednak różnica wysokości między kondygnacjami poszczególnych części budynku.

W przypadku rozbudowy obiektu jego nowe elementy powinny wyróżniać się od najstarszej charakterystycznej części, jednak budynek powinien być spójny ze sobą. W tym celu można np. zastosować jeden materiał na nadbudowę i dobudowaną nową część i dodać jakiś akcent, detal architektoniczny, który scali części budowane w ponad 60 letniej odległości czasowej. Być może warto rozważyć wykorzystanie luksfer w nowej części budyn- 
ku. Projektowana część budynku nie musi mieć cofniętych wyższych kondygnacji. Taki zabieg pozwoli na zachowanie proporcji podziału kamienic w pierzei kwartału. Funkcjonalnie i urbanistycznie korzystnym rozwiązaniem jest ulokowanie biur lub funkcji handlowej od strony nowego targu. W takim przypadku pojawia się kolejna komplikacja w postaci wjazdu do dziedzińca działki lub do garażu podziemnego. Pozostawienie w dotychczasowym miejscu organiczny funkcjonalność budynku od strony targu. Z drugiej strony usytuowanie wjazdu przy Nadstawnej 2, doprowadzi do przerwania części handlowej obiektu na dwa osobne fragmenty. Jednak to rozwiązanie umożliwia przeznaczenie większej części budynku na funkcję handlową, co jest w interesie Inwestora.

Przykład przebudowy lub nowego obiektu zamieszczono na rysunkach 7 i 8 . Jest to wersja optymalna, tzn. pozbawiona wad istniejącego obiektu oraz maksymalizująca wykorzystanie pod funkcję handlową i usługową. Narożne luksfery zostały ograniczone ryzalitami do wymiarów głównego wejścia, tworząc współczesny portal rozciągający się pionowo przez całą elewację. Północna część budynku także została wzbogacona ryzalitami w celu stworzenia spójnej kompozycji całego obiektu. Chcielibyśmy jednak podkreślić, że ten fragment, w przypadku odpowiedniego zagospodarowania planowanego placu targowego, mógłby stworzyć odrębną tożsamość. W tym celu korzystne jest nadanie bardziej zindywidualizowanej formy.

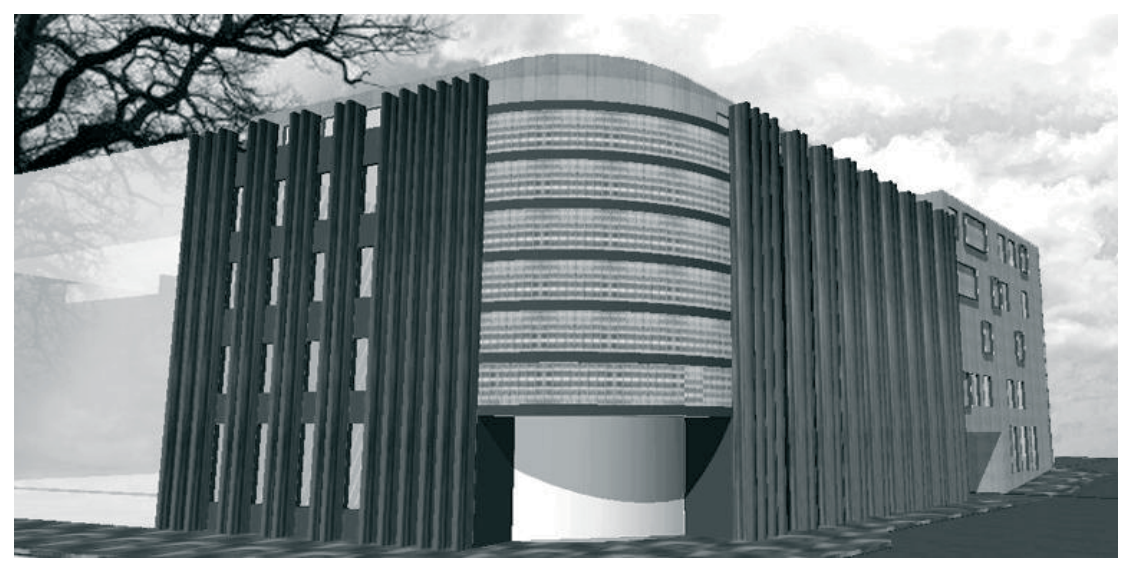

Rys. 7. Widok budynku po modernizacji od strony wejścia głównego - propozycja

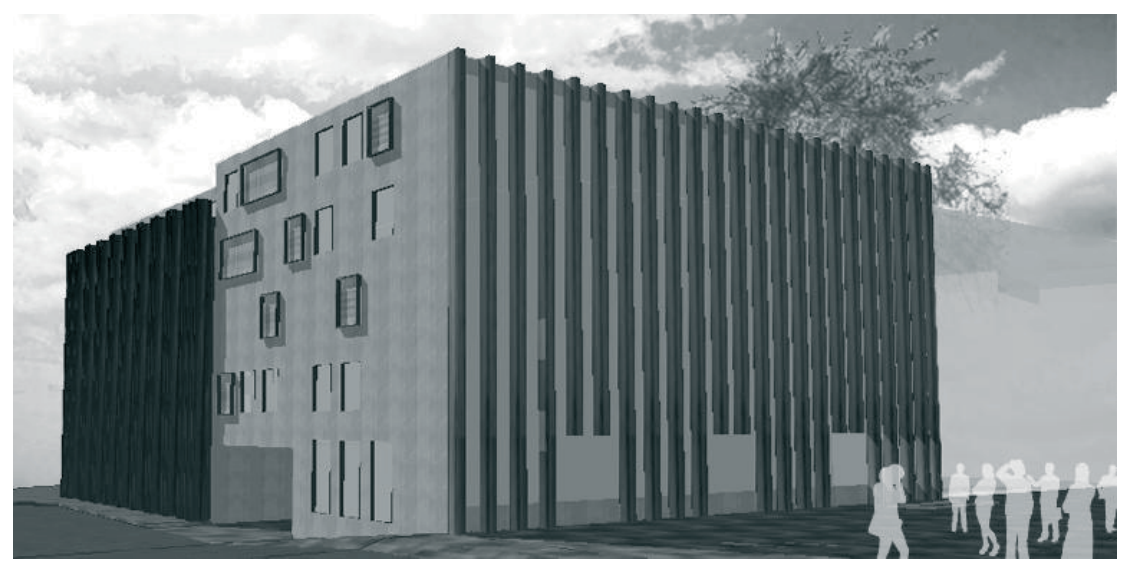

Rys. 8. Widok budynku po modernizacji od strony projektowanego nowego placu targowego - propozycja 


\section{Podsumowanie}

W niniejszej publikacji został przedstawiony budynek przy ul. Nadstawnej 2-4 w Lublinie - jego stan faktyczny oraz możliwości przebudowy zgodnie z przepisami obowiązującego planu miejscowego. Wykonaliśmy badania podłoża oraz osiadania budynku, a także analizy ekonomiczne i architektoniczne.

Wykonane badania i analizy miały na celu wskazać, który scenariusz jest bardziej korzystny dla Inwestora: modernizacja istniejącego obiektu czy budowa zupełnie nowego. Odpowiedź na to pytanie pośrednio mogła dostarczyć informacji na temat uchwalonego w 2015 r. planu miejscowego dla tego rejonu: czy jest on atrakcyjny inwestycyjnie, czy jednak atrakcyjność ta jest kwestią przyszłości. Wykonane przez autorów badania dostarczają jednoznacznej odpowiedzi wobec nowszej części budynku (Nadstawna 4) - pod każdym względem zasadna jest budowa zupełnie nowego budynku. Niejednoznaczna pozostaje kwestia głównej części obiektu (Nadstawna 2). Wykonane analizy ekonomiczne wskazują na możliwą zyskowność nowej inwestycji w standardzie typowym, co może oznaczać wprowadzenie przeciętnego obiektu do centrum miasta. Budowa obiektu wysublimowanej architektury, a przez to skierowanego do konsumentów standardu premium w ocenie autorów jest ryzykowna. Alternatywnym rozwiązaniem jest remont generalny tej części budynku, a przez to utrzymaniu dominującej funkcji handlowej i usługowej. Scenariusz ten jest tańszy od budowy nowego obiektu, a także umożliwia odłożenie decyzji o budowie do czasu wzrostu atrakcyjności tego obszaru. Autorzy przychylają się do takiego rozwiązania. Pozwoli ono na zachowanie modernistycznej formy budynku, wpisanej w otaczającą przestrzeń.

\section{Literatura}

1. Rejestr cen i wartości nieruchomości miasta Lublin, Wyciąg nr GD-TN.6642.394.2015_0663_CL0 z dnia 7.10.2015r., Urząd Miejski w Lublinie.

2. GRUPA PZU S.A, ogłoszenie o przetargu, (https://www.pzu.pl/grupa-pzu/nieruchomosci-nasprzedaz/lubelskie/Lublin-ul.-Nadstawana-2), dostęp: 1.11.2015r.

3. Sekocenbud, Biuletyn cen obiektów budowlanych, stan na III kwartał 2015 r., Warszawa, OWEOB Promocja Sp. z o.o.

4. Smaga D. Kupcy z ulicy ruskiej przeniosa się na druga stronę. Dziennik Wschodni, 11.12.2015 r.

5. Wrana J. Tożsamość miejsca: kryterium $w$ projektowaniu architektonicznym. Monografia, Politechnika Lubelska, 2011.

6. Uchwała Rady Miasta Lublin nr 180/VII/2015 z dnia 21 maja 2015 r. w sprawie uchwalenia miejscowego planu zagospodarowania przestrzennego miasta Lublin w rejonie ulic: Podzamcze, Aleja Tysiąclecia, Lubartowska, Ruska. (http://bip.lublin.eu/bip/um/index.php?t=200\&id=241248).

7. Dokumentacja techniczna badań podłoża gruntowego do projektu technicznego remontu i adaptacji budynku biurowego PZU przy ul. Nadstawnej w Lublinie, GEOPROJEKT - Przedsiębiorstwo Geologiczno-Fizjograficzne i Geodezyjne Budownictwa w Lublinie, 1979.

8. Raport $\mathrm{z}$ badań CPT przy ul. Nadstawnej 2 w Lublinie, GEONEP, 2015. 


\title{
Podzamcze in Lublin - spatial development and opinion on the building Nadstawna 2-4
}

\author{
Lukasz Borowski ${ }^{1}$, Krzysztof Nepelski ${ }^{2}$, Olga Skoczylas ${ }^{3}$ \\ ${ }^{1}$ Geotechnics Department, Faculty of Architecture and Construction Engineering, \\ Lublin University of Technology, e-mail: l.borowski@pollub.pl \\ ${ }^{2}$ Independent Architectural Design Studio, Faculty of Architecture and Construction Engineering, \\ Lublin University of Technology, e-mail: o.skoczylas@pollub.pl \\ ${ }^{3}$ Geotechnics Department, Faculty of Architecture and Construction Engineering, \\ Lublin University of Technology, e-mail: k.nepelski@pollub.pl
}

\begin{abstract}
This article discusses the future of the premise located at 2-4 Nadstawna in Lublin. The reasons behind this publication are not only changes to the purpose of the building in question implemented in the Local Zoning Plan (5.2015) for Podzamcze but also its poor technical condition. This means that the property will not be used for commercial and office-related purposes but, instead, it will be aimed at residential and servicerelated ones. The new owner of the discussed premises (since 02.2015) will therefore need to decide whether to renovate the existing building and omit to change its current function or to erect a new property in compliance with the local zoning plan being in force at present. The authors of this article are of the opinion that this decision will be of considerable importance for developing the space in this part of the city.

For the purposes of this publication, Borowski, Skoczylas, and Nepelski analysed the technical condition of the property, investment funds to be allocated, optimal development of the building, modernisation and extension plans, as well as the influence that the property may exert on the surrounding area. Furthermore, the reasons and results of building subsidence were also investigated.
\end{abstract} probing.

Keywords: the future of Podzamcze, modernism in Lublin, building subsidence, CPT 
